\title{
Relational ways of being an educator: trauma-informed practice supporting disenfranchised young people
}

\author{
Ann Morgan*(a) Donna Pendergast (a), Raymond Brown (a), Deborah Heck (b)
}

(a) School of Education and Professional Studies, Griffith University, Gold Coast, Australia;

(b) School of Education, University of the Sunshine Coast, Sippy Downs, Australia.

*Corresponding author. ann.morgan2@griffithuni.edu.au

\section{Notes on contributors}

Ann Morgan explored educator identity and development in alternative education contexts in her doctoral thesis, using a sociocultural qualitative research paradigm. She has had extensive work experience in the fields of mainstream and alternative education. Dr Morgan works with education practitioners in flexi schools to support them in professional learning with a particular emphasis on educator identity, relational dynamics and critical reflective practice.

Donna Pendergast has conducted research in the following areas: middle years education; middle schooling; early years education; school and policy reform and evaluation; Year 7 into secondary; resilience; generational theory; $\mathrm{Y}$ and $\mathrm{Z}$ generations and pedagogy; teacher efficacy; family and consumer sciences research; home economics philosophy; cyberbullying; mentoring; evaluation of professional development processes; food literacy; gifted and talented students. Professor Pendergast currently holds the position of Head and Dean, School of Education and Professional Studies, Griffith University.

Raymond Brown has conducted research in the following areas: professional and teacher learning communities; co-operative/collaborative models of learning and teaching; mathematics education; values education; teacher attitudes, beliefs and funds of knowledge; and school renewal. Dr Brown is Associate Professor in the School of Education and Professional Studies, Griffith University.

Deborah Heck's research interests include the exploration of change in education including: values education and school renewal, science education, environmental education and ICTs and teacher education. She is Associate Professor in the School of Education at the University of the Sunshine Coast. 


\begin{abstract}
Despite complex reasons for disengagement and exclusion from conventional schooling, all children have a right to education that is of a high quality. Disenfranchised young people require alternatives for re-engaging in education. This necessitates a rethinking of what it means to be an educator in alternative education settings and how to relate to young people who have experienced exclusion and failure in conventional school settings. Relational ways of being educator are vital to support the creation of lifelong learners, not merely school completers. Flexible learning programs offer a model of re-engagement in which relational ways of being educator are prioritised. This article explores key aspects of trauma-informed practice and relational pedagogy in a network of flexi schools in Australia. Relational pedagogy can redress the impact of trauma and social exclusion experienced by young people. In flexi schools educator identities are challenged and changed by a willingness to explore and understand the impact of trauma on young people's development and capacity to learn. A commitment to trauma-informed practice and relational pedagogy requires educator identities to be co-constructed and negotiated in relationship with young people and colleagues. These shifts in educators' sense of identity in the flexi schools context are explored.
\end{abstract}

Keywords: disenfranchised young people; relational pedagogy; trauma-informed practice; educator identity.

\title{
Introduction
}

Different ways of being an educator are required in order to re-engage young people facing multiple complexities in their lives (Morgan, Brown, Heck, Pendergast \& Kanasa, 2013). This article highlights the importance of trauma-informed practice and relational pedagogy in flexible learning contexts as strategies for re-engagement. These ways of working with young people require shifts in educator's sense of identity and development in practice. Three focal points related to teacher professional identity (TPI) evident in the literature will be explored: the emotional dimension of TPI including the notion of teacher as carer; the impact of reform agendas on TPI, and the influence of context on TPI (Lasky 2005, Noddings 1992; Smyth 2007). These focal points address a particular gap in the literature related to TPI in alternative education contexts specifically developed to enfranchise young people. They are aligned with features of best practice in these contexts identified in the literature (de Jong and Griffiths 2006). 


\section{Educational outcomes for young people in Australia}

The connection between educational outcomes and socio-economic status is more significant in Australia than in many other comparable countries. The rate of school completion for young Australians from low socio-economic status is significantly lower than for other young Australians (Council of Australian Government Reform Council 2013). Of serious concern is that of the $20 \%$ who do not finish year 12 or its equivalent, there is an over-representation of students who are Indigenous, those living in remote and very remote regions of Australia, and those from low socioeconomic groups (Foundation for Young Australians, 2013).

The disparity in educational outcomes for some young Australians is deeply concerning in terms of social inclusion and social justice. Other ways of providing education that are cognisant of trauma-informed practice and relational pedagogy are available in an increasing range of flexible learning programs that support young people to remain engaged in education.

\section{Reform agendas and the nature of educational provision}

For young people who have experienced trauma, neglect or abuse, or those whose lives and school attendance have been impacted by poverty, generational unemployment, homelessness or high mobility, or the impact of substance abuse within families or mental illness, attending school poses challenges that for some are overwhelming. Whilst school completion lessens the likelihood of unemployment, the reasons for non-completion of schooling are not only related to social and economic factors.

Suspension, expulsion or early school leaving and subsequent disenfranchisement of some young people may be indicative of a lack of ability of a system to accommodate the diversity of students' life circumstances and learning needs. Identifying young people as the 
source of the problem (te Riele 2007) indicates the failure of conventional school systems to address the needs of marginalised young people. This problem is recognised as a limitation of a system struggling to renew and update to more contemporary pedagogies that are studentcentred and responsive to the changing needs of young people in contemporary society (Kalantzis and Cope 2005; Whitby 2013; Wyn 2008).

The creation of alternative schools has been viewed by some as an attempt to address the need for more inclusive, student-centred educational options (Edmund Rice Education Australia 2010). This trend of creating alternative schools has been criticised as another form of segregated schooling (de Jong and Griffiths 2006; Slee 2011). However, researchers in this field have also indicated that there are lessons from alternative schools that might inform inclusive education within conventional schools (Holdsworth 2004; Mills and McGregor 2013; te Riele 2007). In particular, an understanding of the importance of trauma-informed practice and relational pedagogy to engage disenfranchised young people is critical.

\section{Trauma-informed practice and relational pedagogy}

Trauma-informed practice takes into account how experiences of trauma, such as abuse and neglect, can impact on children and young people's brain development and subsequently on their capacity to learn. Not all children or young people who exhibit challenging behaviour have suffered abuse and neglect. They may have other issues related to temperament, disability, or medical and health conditions that make learning in classroom settings extremely difficult (Downey 2009). Whilst the individual needs of each child or young person must be understood and responded to, an appreciation of trauma-informed practice is essential for staff working in flexi school settings. The impacts of trauma, neglect and abuse are varied, but may include:

- neurological and learning difficulties; 
- affect dysregulation;

- relationship difficulties;

- attachment difficulties;

- shame;

- $\operatorname{mood}$ and attention problems;

- problem behaviours; and/or

- hyperarousal and dissociation (Downey 2009, 23).

The importance of prioritising relational pedagogy (Bingham and Sidorkin 2004), which involves building relationships of trust and safety that support the development of social and emotional foundations for cognitive learning, cannot be underestimated. According to Downey (2007) abuse and neglect have a twofold effect on children and young people, impacting on academic performance and social functioning. "Reduced cognitive capacity; sleep disturbance (causing poor concentration); difficulties with memory (making learning harder); and language delays (reducing capacity for listening, understanding and expressing)" affect academic performance (Downey 2007 11). Additionally, the impacts of abuse and neglect on children's social functioning include: "the need for control; attachment difficulties (including attachment to school); poor peer relationships; and the instability arising from frequent moving" (Downey 2007, 13).

The impact of having teachers who may not have the education, experience and capacity to meet the complex social and academic needs of disenfranchised young people, highlights a broader social problem in education (Dwyer and Wyn 2001; Smyth and Hattam 2004; Warren 2005). This problem exists when the blame for poor academic outcomes is located within the students themselves rather than being explored through an interrogation of "educational provision" in order to meet the needs of children and young people (Deschenes, 
Cuban and Tyack 2001; Hodgson 2007; Smyth and Hattam 2004; te Riele 2007, 56).

Privileging the academic needs of students over their need for health and wellbeing (Noddings 2005a, 2005b) reinforces dualistic thinking that is not helpful when working with disenfranchised young people whose needs are complex and include social, emotional, physical, spiritual and intellectual needs.

\section{Educator identity}

The ways that teachers perceive learners is connected in some ways to their sense of professional identity - how they perceive themselves as educators and the various influences that shape this perception (Beijaard, Verloop and Vermunt 2000). Educator identity is significant in terms of the way it shapes and influences practice - both consciously and unconsciously. Critical reflection on professional identity is essential in order to offer innovative, relevant and meaningful responses to young people, especially those who are disenfranchised (Morgan et al, 2013; Morgan, Pendergast, Brown and Heck, 2014).

\section{The emotional dimension of Teacher Professional Identity (TPI) - teacher as carer}

The professional identity of teacher as carer (Noddings 1992) is especially pertinent when considering low achieving students who are more at-risk of becoming early school leavers (Hodgson 2007; Smyth and Hattam 2004). The development of mutually respectful and caring teacher-student relationships forms the basis of re-engagement (Bingham and Sidorkin 2004; Hirst and Vadeboncoeur 2006; Smyth 2007). The quality of robust relationships developed through openness between educators and young people, has been directly linked with student learning and teachers' beliefs that their role with students included "helping in their social and emotional development, along with delivering the academic skills" (Lasky 2005, 907). Caring for students and/or fostering their cognitive 
development are not seen as mutually exclusive, and these two aspects of educators' professional identity can be held in balance and integrated (Lasky 2005; O'Connor 2008).

\section{The impact of educational reform agendas and context on TPI}

Questions around what constitutes learning and who decides this (Noddings 2005a; Sachs 2001) can impact on teacher professional identity. Negative impact on teachers' workload and sense of agency increase as teachers feel challenged to meet the needs of students who face "moral, social, and emotional dilemmas" in the midst of uncertainty and significant social change (Beijaard et al. 2000, 751).

Most of the research exploring teacher professional identity has been conducted in conventional school settings. Minimal research is available on teacher identity in alternative schools with multidisciplinary staff teams (Morgan et al. 2013). Consideration of educator identity cannot be separated from the particular context including the kinds of relationships and agency that shape and form identity (Beijaard et al. 2000; Lasky 2005).

\section{Relational ways of being an educator}

In response to contemporary reform agendas that have been perceived as market driven, with a narrow focus of the nature and purpose of education, prioritising relational pedagogy has re-emerged as a way of being educator (Beck and Cassidy, 2009; Bingham and Sidorkin 2004; Hargreaves 2001). Prioritising relationships can redress the overemphasis on standardised testing and unreasonable accountability measures for teachers and schools, promoting teaching and learning that is more young person-centred.

Young people who face uncertainties related to discrimination, social exclusion, trauma and neglect require a different model of interaction with adults than what may be experienced in more conventional educational settings. This can redress the "relational poverty" they have experienced (Downey 2009; Perry 2009, 250). An holistic approach to 
teaching and learning that is inclusive of teacher roles such as carer and academic facilitator and guide and an awareness of trauma-informed practice, can make a significant difference for young people who may have experienced the impact of abuse, trauma or neglect (Downey 2010; Perry 2001; Perry 2009). Awareness of other issues including cultural and/or socioeconomic diversity, health issues (physical or mental), different abilities or specific learning needs can enable teachers to differentiate curriculum accordingly in response to each individual young person.

\section{Relational pedagogy for wellbeing and democratising the learning space}

The practice of educators that has emerged in flexible learning programs emphasising safe and supportive relationships is identified in the literature as a feature of best practice in alternative education settings (Morgan 2013; Morgan et al. 2013; Morgan et al. 2014; Mills and McGregor 2013). Increasing awareness of trauma-informed practice reinforces the significance of developing authentic relationships with young people as a way of restoring their capacity for connection and learning (Downey 2009). Due to the predominantly negative experiences of disenfranchised young people in conventional school settings, educators in the flexi schools have to find different, more relational ways of working with this group of young people. Relational pedagogy promotes experiential learning of democratic processes in relationships in the learning community and promotes active listening to young peoples' voice. It recognises their agency and respects their capacity to choose and navigate their own learning trajectories. This changes adults' and young peoples' experiences of authority and power in education (Bingham and Sidorkin 2004, Smyth 2006) and their sense of identity as co-learners.

These ways of working, considered to be effective by practitioners in the context, are reinforced in the research literature (te Riele 2012; te Riele 2014) and are primarily relational 
in nature. Educators in flexible learning programs aim to maintain a balanced perspective between formal education and young person welfare. They place a strong emphasis on positive relationships rather than punitive behaviour management that can be demeaning for young people. This requires proactive, rather than reactive responses to young people who need support and encouragement to actively participate and take responsibility for their learning (de Jong and Griffiths 2006). For educators, seeing themselves as being and becoming relational in this way of working with young people, requires them to be more fully themselves in order to break down hierarchical relationships with young people (Nabavi and Lund 2010).

\section{The study reported in this article: methodology}

The study reported in this article explored how ways of working and ways of professional learning influenced educator identity and development in practice in a network of five flexi schools in Queensland, Australia. A twofold objective was embedded within the research design. First, exploring the contextual influences in practice in flexi schools by considering how ways of working and ways of professional learning influence educator identity and development. Second, enhancing staff induction processes through prototyping Reflective Practice Groups (RPGs) as a strategy for supporting the development of educators as reflective practitioners. Becoming more self-aware in order to be more aware of one's relationships with others, including young people and colleagues, supports diversity within the learning community (Morgan et al. 2014).

The research methodology based on Bannan Ritland's (2003) model of design experiment included three stages: exploration; enactment; and evaluation. This methodology encouraged consultation with educators in five flexi schools using iterative cycles of reflection throughout the implementation of the design experiment (Collins, Joseph, and 
Bielaczyc 2004). Data gathered in Stage One: exploration consisted of questionnaires $(\mathrm{N}=30)$ and interviews $(\mathrm{N}=16)$. In Stage Two: enactment, researcher journal entries $(\mathrm{N}=13)$ reflecting on the experience of co-facilitating Reflective Practice Group (RPG) sessions were the data collection method. The final data collection method used in Stage Three: evaluation, consisted of participants' written evaluations $(\mathrm{N}=20)$ of their experiences in the RPG sessions. Analytic tools for these various methods included descriptive statistics (Babbie 2004), thematic content analysis (Braun and Clarke 2006), and thematic network analysis (Attride-Stirling 2001). Peer researchers acting as critical friends (Carr \& Kemmis 1986) assisted with data coding and analysis of some datasets providing inter-rater authenticity (Cohen, Manion, and Morrison 2007; Gay, Mills, and Airasian 2006). A summary of data collection methods, recruitment processes for participants, and details of participants for each stage of the design experiment are included in Table 1.

Table 1.

Data Collection Methods, Participant Recruitment and Participant Details for each stage of the Design Experiment,.

\begin{tabular}{|c|c|c|c|}
\hline $\begin{array}{l}\text { Design } \\
\text { Experiment }\end{array}$ & Data collection methods & Participant recruitment processes & Participant details \\
\hline \multirow[t]{2}{*}{$\begin{array}{l}\text { Stage One: } \\
\text { Exploration }\end{array}$} & Questionnaire & $\begin{array}{l}\text { Invitation to staff in five flexi } \\
\text { schools to participate (voluntary } \\
\text { participation) }\end{array}$ & $\begin{array}{l}\mathrm{N}=80 \\
37.5 \% \text { Response rate } \\
63 \% \text { female } 37 \% \text { male } \\
10 \text { different staff roles }\end{array}$ \\
\hline & Interviews & $\begin{array}{l}\text { Invitation given to all staff to be } \\
\text { interviewed. Those interested } \\
\text { volunteered. }\end{array}$ & $\begin{array}{l}\text { Volunteer participants } \\
\mathrm{N}=16 \text { ( } 20 \% \text { of staff) } \\
56 \% \text { female } 44 \% \text { male } \\
69 \% \text { teachers } 31 \% \text { other roles } \\
\text { from community service } \\
\text { sector workforce }\end{array}$ \\
\hline $\begin{array}{l}\text { Stage Two: } \\
\text { Enactment }\end{array}$ & $\begin{array}{l}\text { Researcher reflective } \\
\text { journals on experience of } \\
\text { facilitating Reflective } \\
\text { Practice Groups (RPGs) }\end{array}$ & Researcher & $\begin{array}{l}\mathrm{N}=13 \\
\text { Researcher was the only } \\
\text { participant }\end{array}$ \\
\hline $\begin{array}{l}\text { Stage Three: } \\
\text { Evaluation }\end{array}$ & $\begin{array}{l}\text { Written evaluations from } \\
\text { RPGs }\end{array}$ & $\begin{array}{l}\text { New staff in five flexi school } \\
\text { sites were asked to participate as } \\
\text { part of their induction. } \\
\text { Participants completed written } \\
\text { evaluations after the first and } \\
\text { second sessions. }\end{array}$ & $\begin{array}{l}\mathrm{N}=20 \\
60 \% \text { teachers } 40 \% \text { other roles } \\
55 \% \text { female } 45 \% \text { male }\end{array}$ \\
\hline
\end{tabular}


This article focuses on questionnaire data and those items that explored educators' perceptions of their professional identity. Some reference to interview data emphasising relational pedagogy is also made to show the consistency of the key theme of 'relationships' across the datasets. In depth details of interview data analysis using thematic content analysis and thematic network analysis is beyond the scope of this article and are reported elsewhere (see Morgan et.al. 2013; 2014). Finally, the influence of relationships on educator identity and development in practice is highlighted.

\section{Questionnaire data and educator identity}

Three questionnaire items explored educators' perceptions of themselves as educators and their priorities in their work with young people. Staff were asked to write five words that described themselves as an educator within their current role/s and what they considered to be five most important aspects of their work. Respondents were also invited to identify metaphors of themselves as educators in flexi schools. A list of metaphors was provided or participants could create their own metaphor. Brief written explanations of the meaning of the metaphor were requested. The analytic tool applied to the datasets was thematic content analysis. For each item responses were categorised under word headings and then these categories were grouped under key themes. The identification of headings for word categories and key themes was influenced by features of best practice in alternative education identified in the literature review.

\section{Summary of findings from questionnaire data analysis}

\section{Descriptive words of self as educator}

Staff perceptions of themselves as educators, captured in five descriptive words, aligned with the key themes that were identified in interview data analysis describing ways of 
working with young people. Some of these key themes included 'relationships' and 'listening to young people'. Specific details of procedures for interview data analysis are beyond the scope of this article and are reported elsewhere (Morgan et al. 2013; 2014). As was the case in interview data analysis, questionnaire data analysis of 'descriptive words of self as educator', showed the significance of relationships and re-engagement strategies. Some other key themes were apparent but to a lesser extent. The 'relationships' theme was evident in word categories collated under headings such as carer, mentor, guide. and included words such as helpful, compassionate, caring, supportive, understanding, patient, mentor, guide, trustworthy, challenging and role model. The 're-engagement' theme was apparent in word categories collated under headings such as organiser/designer, facilitator and motivator, and included words such as organised, efficient, skills developer, flexible, enthusiastic and passionate. Table 2 shows how the questionnaire data analysis aligned with key themes identified in interview data analysis. The frequency of the appearance of the categories across the questionnaire dataset is also included in the table highlighting the significance of relationships and re-engagement strategies in educators' work with young people.

Table 2

Descriptive Word Categories from Questionnaire Data Analysis with Links to Key Themes Identified in Interview Data Analysis and Prioritised Number of Instances

\begin{tabular}{|c|c|c|c|c|c|c|c|}
\hline \multirow{2}{*}{$\begin{array}{l}\text { Descriptive } \\
\text { Word } \\
\text { categories }\end{array}$} & \multirow{2}{*}{$\begin{array}{l}\text { Links to key themes in ways } \\
\text { of working with YP from } \\
\text { interview data analysis }\end{array}$} & \multicolumn{5}{|c|}{ Order of priority of word categories } & \multirow{2}{*}{$\begin{array}{c}\text { Total } \\
\text { number of } \\
\text { instances }\end{array}$} \\
\hline & & First & Second & Third & Fourth & Fifth & \\
\hline Carer & Relationships & 6 & 8 & 13 & 6 & 10 & 43 \\
\hline Facilitator & $\begin{array}{l}\text { Re-engagement \& Listening } \\
\text { to young people }\end{array}$ & 8 & 5 & 3 & 11 & 6 & 33 \\
\hline $\begin{array}{l}\text { Organiser/ } \\
\text { Designer }\end{array}$ & Re-engagement & 5 & 8 & 3 & 4 & 3 & 23 \\
\hline Mentor/Guide & Relationships & 5 & 4 & 5 & 5 & 3 & 22 \\
\hline Motivator & $\begin{array}{l}\text { Re-engagement \& Changing } \\
\text { perspectives }\end{array}$ & 7 & 4 & 4 & 1 & 2 & 18 \\
\hline Miscellaneous & Not applicable & 2 & 1 & 1 & 3 & 6 & 13 \\
\hline & & & & & & TOTAL & 152 \\
\hline
\end{tabular}




\section{Most important aspects of work}

Questionnaire respondents were asked to list what they considered to be five important aspects of their work. Data were collated into categories which included: caring and supporting; mentoring and guiding; motivating; organising and designing; facilitating; life learning and community networking; miscellaneous and life learning and community networking. Table 3 presents the categories of participants' perceptions of their five most important work priorities. Links to key themes identified in interview data analysis are included in column two of the table. The frequency of their appearance across the questionnaire dataset is included in the table with similar results to the previous questionnaire item.

Table 3

Categories of Most Important Aspects of Work from Questionnaire Data Analysis with Links to Key Themes Identified in Interview Data Analysis and Prioritised Number of Instances

\begin{tabular}{|c|c|c|c|c|c|c|c|}
\hline \multirow{2}{*}{$\begin{array}{l}\text { Categories of most } \\
\text { important aspects } \\
\text { of work }\end{array}$} & \multirow{2}{*}{$\begin{array}{l}\text { Links to key themes in ways } \\
\text { of working with YP from } \\
\text { interview data analysis }\end{array}$} & \multicolumn{6}{|c|}{ Order of priority of word categories } \\
\hline & & First & Second & Third & Fourth & Fifth & TOTAL \\
\hline Caring \& supporting & $\begin{array}{l}\text { Relationships } \\
\text { Listening to young people }\end{array}$ & 17 & 7 & 4 & 5 & 1 & 34 \\
\hline Facilitating & Re-engagement & 1 & 6 & 3 & 5 & 8 & 23 \\
\hline $\begin{array}{l}\text { Organising \& } \\
\text { designing }\end{array}$ & Re-engagement & 0 & 5 & 7 & 5 & 4 & 21 \\
\hline Motivating & Re-engagement & 2 & 5 & 5 & 2 & 1 & 15 \\
\hline $\begin{array}{l}\text { Life learning \& } \\
\text { community } \\
\text { networking }\end{array}$ & $\begin{array}{l}\text { Relationships } \\
\text { Re-engagement }\end{array}$ & 1 & 1 & 4 & 3 & 1 & 10 \\
\hline Mentoring \& guiding & Listening to young people & 2 & 2 & 1 & 2 & 0 & 7 \\
\hline Miscellaneous & Not applicable & 0 & 0 & 0 & 0 & 0 & 0 \\
\hline & & & & & & TOTAL & 110 \\
\hline
\end{tabular}

Approximately $65 \%$ of respondents' first work priority was linked to the key theme of relationships. Relational work priorities included statements such as: nurturing students; building trust/rapport; patience; building relationships; young peoples' welfare; and, developing relationships with young people that are trusting and positive.

The most frequently identified second work priority of respondents was linked to the 
key theme of re-engagement (approximately 35\% of respondents). Re-engagement priorities included statements such as: empowering students to want to learn; innovative curriculum; teaching life skills; creating opportunities and options for learning in context in cooperation with young people's aspirations; options advisor; and, implementing programs outside the traditional square.

\section{Metaphor images}

The use of metaphors was adopted in the questionnaire to elicit educators' perceptions of their professional identity. In the explanations of metaphor choices there were many instances where the reasons aligned with the key themes identified in the interview data analysis of ways of working with young people. Table 4 highlights the key themes from interview data analysis and the instances where explanations aligned with these key themes.

Table 4

Key Themes in Ways of Working with Young People from Interview Data Analysis and Instances of Metaphors that Aligned with Key Themes

\begin{tabular}{lc}
\hline $\begin{array}{l}\text { Key themes in interview } \\
\text { data analysis }\end{array}$ & $\begin{array}{l}\text { Instances of metaphors } \\
\text { that aligned with key } \\
\text { themes }\end{array}$ \\
\hline Relationships & 10 \\
Re-engagement & 9 \\
Holding Complexity & 5 \\
Structure \& Boundaries & 4 \\
Listening to Young People & 3 \\
Strengths-based Practice & 3 \\
Connections & 3 \\
Time & 2 \\
Changing Perspectives & 1 \\
\hline Other categories & \\
\hline No reason given for choice & 6 \\
Miscellaneous metaphors & 4 \\
Would identify respondent & 2 \\
\hline No response & 1 \\
\hline
\end{tabular}

Below are two examples of metaphors with explanations from educators. These capture the key themes of relationships and re-engagement: 
1. Dolphin in river (group of dolphins) - A river is the metaphor for the journey of learning. It changes with the seasons but has boundaries within which one operates. Students come to me towards the higher end of their learning journey. As the dolphin I guide, pick up signals, work in with the group, have fun, have compassion and care but also leap into jumps beyond the comfortable known and regroup when needed, still within boundaries and picking up speed towards the ocean.

2. A dancer in improvisation - As a dancer I have my ever growing kit bag of moves, dynamics, rhythms, tempos, strength, flexibility, speeds to draw on when the context seems right. I am improvising constantly on the diversity of themes presented by the young people and others in the community. The improvisation is fed by the dance in me wanting to come out and all the dance in others that calls for response or accompaniment or simple stillness. It needs constant attention and "aliveness".

In the questionnaire data analysis, staff perceptions of their roles and sense of professional identity were evident in descriptors of themselves as educators, the five most important aspects of their work, and metaphors of themselves as educators. Analysis of questionnaire data showed alignment with the key themes from ways of working with young people that were identified in analysis of interview data. In particular, the key themes of relationships and re-engagement appeared consistently. Educators prioritised the relational aspect of their work with young people and gave precedence to developing strategies for reengagement of young people in learning choices that were flexible, meaningful and relevant. Other key themes from interview data analysis that were also evident in the questionnaire data were included listening to young people, strengths-based practice and the agency of young people. Staff perceptions of themselves as educators and their perceptions of the most 
important aspects of their work with young people, were unambiguously relational in the first instance, with an emphasis on strategies for re-engagement. Two key strategies for reengagement that were evident in interview data were listening to young people and taking time.

\section{Listening to young people}

As educators with a teaching background became more comfortable with prioritising their relational educator identity and recognised the significance of emphasising relationships with young people as the starting point of their work, they seemed to be able to listen more effectively to young people. One of the teachers had a strong sense of the need to listen to young people in order to understand them and to be directed in action by their expressed needs. "I think that's the essence of it, if we keep as adults getting back to listening to young people and what they're looking for" (INT 16, p. 5). The commitment to listen to young people was perceived by another participant to be driven by confidence in young people's resilience and capacity to cope. This was described as:

[L]istening, listening, listening and then trying to act upon what you hear with the understanding that often what young people say is not often what they mean and trying to keep talking and listening so that you can find out what they mean ... not to fix the issue or their problem, but to help give them ways to look at it and cope with it. (INT 10 p. 1)

The data indicates that when educators were actively listening to young people they more often experienced greater freedom to implement re-engagement strategies and provide more suitable learning options for this group of young people. Active listening can be defined as the capacity to listen sensitively to another (Rogers and Farson 1957), showing “responsivity and empathy" (Hutchby 2005, 304). 
Taking time - time to care (Noddings 1992), time to develop safe and supportive relationships (Beck and Cassidy 2009) and appreciating time in the learning process (Cassidy and Chinnery 2009), were other key themes in understanding the needs of young people that were evident in flexi school practitioners' perspectives of their work with young people. It was essential that taking time be valued as an aspect of practice in the work, as articulated in the following comment:

[I]t takes time ... We have to work with young people, and take the time that it takes to get them through. What many of the young people are dealing with in their lives just does not fit neatly between school times. If that is happening we need to be prepared to stay connected with them for a lot longer than the usual two or three year senior. (INT 01, p.20)

In emphasising how trauma affects some young people's capacity to interact constructively with others and engage positively with learning, one interviewee highlights the need for knowledge. She commented that staff need:

[A] constant reminder of the nature of our young people and why they are the way they are, which is like the trauma and the effect of abuse ... there's so much other stuff going on and the more we are reminded of that the more we can have the patience and tolerance [and] feel more passion towards them and compassion ... And you can't do that unless you've got the knowledge. (INT 15, p. 5)

\section{Discussion: how practice in flexi schools influences educator identity}

Relational practice in the flexi schools' context influences educator identity both at a personal level and at an interpersonal level. This was evident in data analysis of questionnaire items exploring educator identity that identified respondents' perceptions of themselves as educators in word descriptors, in metaphors and in their perceptions of the most important aspects of their work. This emphasis on relationships was also evident in the 
interview data analysis as educators described the ways they learnt about this relational way of working with young people. Through seeing other more experienced educators working relationally with young people, and through talking with peers in debrief and reflective practice sessions, workers gave themselves permission to perceive themselves in the first instance as relational beings.

\section{Making connections: how trauma-informed practice and relational pedagogy influence shifts in educator identity and development in practice}

As educators support young people to make connections for wellbeing and to reduce the risk of isolation, both within the school community and the wider community, educators' sense of identity and development in practice is influenced. For teachers, this shift requires working outside some of the common boundaries of practice experienced in conventional school settings, for example, outside of traditional classroom settings. For youth workers, social workers and other workers from community welfare backgrounds this emphasis on relationships sometimes provides an opportunity for validation of the ways of working that are common in their professional practice.

Learning about the impact of neglect and trauma on young people's ability to learn, to regulate their emotions and moods, to be able to be attentive, to be able maintain relationships and avoid problem behaviour such as hyperarousal and dissociation (Downey 2007) is vital. Trauma-informed practice gives practitioners a framework that promotes understanding of young people rather than resorting to the tendency to blame young people for their behaviour. When staff develop an awareness of the impact of trauma and/or neglect on young peoples' capacity to learn and develop relationships, they are more equipped with strategies to address these issues. One key strategy includes prioritising safe and supportive relationships (Downey 2009). Educators' sense of compassion seems to increase as they 
develop an understanding of trauma-informed practice. This shift towards greater understanding and the ability to develop relational strategies to support young people, seems to change their sense of professional identity in the context of flexi schools (Morgan et al. 2013).

\section{Shifting towards developing personal and relational qualities}

The emphasis on being an educator who prioritises relationships first has other implications for the ways the flexi schools' context influences educator identity and development in practice. A range of personal qualities of educators were identified in interviews. These were perceived by staff to enhance relationships with young people and over time, support positive engagement. Some of these qualities included wisdom, patience, humour, acceptance of where young people are at, being young at heart, being sensitive, caring, tolerant, compassionate and empathetic. Being able to show their human and emotional qualities through being caring, being open, having a sense of humour and being respectful of the dignity of each young person facing complex circumstances requires a shift in educator identity. For educators who are teachers, this requires a shift in identity from primarily being a deliverer of curriculum and attaining measurable outcomes, to being and becoming a person in an authentic relationship with young people as a starting point. It requires high levels of emotional intelligence and self-awareness.

\section{The influence of context on educator identity and development in practice}

The context of flexi schools supports the identity and development of educators as relational, caring, emotionally intelligent, and critically reflective practitioners, able to respond to the particular complex needs of young people. Being and becoming an educator in flexi schools requires interrogation of current educational reform agendas that are often irrelevant and unsupportive of the re-engagement of disenfranchised young people. At times 
this creates tension and complexity that requires particular skill sets and ways of working with young people and colleagues that are different to those required in conventional school settings (Morgan et al. 2014).

\section{In conclusion}

The exploration of educators' perceptions of their professional identity in the research reported in this article offers deeper understanding of the embedded social and cultural features of the flexi schools' context that influence and shape processes of being and becoming an educator working to enfranchise young people. This was achieved through examination of educators' perceptions of self and priorities in their work with young people captured in the data analysis of the questionnaire and interviews. Whilst this article has mainly focussed on questionnaire data, similar themes that emerged in interview data (Morgan et al. 2013) were briefly explored.

Through analysis of staff perceptions of the ways they worked with young people and colleagues in the flexi schools' context, a number of shifts in educators' sense of identity were identified. Initially, these shifts were connected to the primacy of relationships as the starting point for re-engaging young people. Authentic relationships with young people and staff were characterised by certain dispositions of educators including being fully human, open and respectful. Safe and supportive relationships with young people were developed through informal education and working outside the boundaries of traditional classrooms. Genuinely listening to young people in order to focus on their individual learning needs supported the development of learning choices that were young person-centred, traumainformed and relational in nature. These shifts in identity and development in the practice of educators in flexi schools supported the re-engagement of young people in relevant and meaningful learning trajectories. In this regard, the identity of educators in flexi schools can inform practices in other education settings for the benefit of young people who struggle to 
remain engaged to access their right to education of a high quality.

\section{References}

Attride-Stirling, Jennifer. 2001. "Thematic networks: an analytic tool for qualitative research." Qualitative Research in Psychology no. 1 (3):385-405. doi: 10.1177/146879410100100307.

Babbie, Earl. 2004. The practice of social research. 10th ed. Belmont, California: Thomson, Wadsworth.

Bannan-Ritland, B. 2003. "The role of design in research: The integrative learning design framework." Educational Researcher no. 32 (1):21-24.

Beck, K, and W Cassidy. 2009. "Embedding the ethic of care in school policies and practices." In Making schools different:Alternative approaches to educating young people, edited by K Te Riele, 55-64. London: Sage Publications.

Beijaard, Douwe. 1995. "Teachers' prior experiences and actual perceptions of professional identity." Teachers and Teaching: Theory and Practice no. 1 (2):281-294. doi: 10.1080/1354060950010209.

Beijaard, Douwe, Nico Verloop and Jan, D Vermunt. 2000. "Teachers' perceptions of professional identity: An exploratory study from a personal knowledge perspective." Teaching and Teacher Education, 16, 749-764. doi: 10.1016/S0742-051X(00)00023-8

Bingham, Charles. 2004. "Let's treat authority relationally." In No Education Without Relation, edited by C. Bingham and A. M Sidorkin, 23-37. New York: Peter Lang.

Bingham, Charles, and Alexander M Sidorkin. 2004. No education without relation. New York: Peter Lang.

Braun, V , and V Clarke. 2006. "Using thematic analysis in psychology." Qualitative Research in Psychology no. 3 (2):77-101.

Carr, W, and Stephen Kemmis. 1986. Becoming critical: Education, knowledge and action research. London: Falmer Press.

Cassidy, W, and A Chinnery. 2009. "Learning from indigenous education." In Making schools different: Alternative approaches to educating young people, edited by $\mathrm{K} \mathrm{Te}$ Riele. London: Sage.

Cohen, L, L Manion, and K Morrison. 2007. Research methods in education. 6th ed. London: Routledge.

Collins, A, D Joseph, and K Bielaczyc. 2004. "Design research: Theoretical and methodological issues." The Journal of the Learning Sciences no. 13 (1):15-42. doi: 10.1207/s15327809j1s1301_2.

Council of Australian Government Reform Council. 2013. Education in Australia 2012: Five years of performance. Sydney: COAG Reform Council.

Croninger, Robert, and Valerie Lee. 2001. "Social capital and dropping out of high school: Benefits to at-risk students of teachers' support and guidance." Teachers College Record no. 103 (4):548-581.

de Jong, Terry, and Coojse Griffiths. 2006. "The role of alternative education programs in meeting the needs of adolescent students with challenging behaviour: Characteristics of best practice." Australian Journal of Guidance and Counselling no. 16 (1).

Day, Christopher. and Judyth Sachs. 2005. International handbook on the continuing professional development of teachers Columbus, $\mathrm{OH}$ : Open University Press 
Department of Education Employment and Work Relations. 2009. Australian Government Fact Sheet: Compact with Young Australians - Increasing Educational Attainment of Young People aged 15-24.

Deschenes, Sarah, Larry Cuban, and David Tyack. 2001. "Mismatch: Historical perspectives on schools and students who don't fit them." Teachers College Record no. 103 (4):525 $-547$.

Downey, L. 2007. Calmer classrooms: A guide to working with traumatised children. Melbourne, Victoria: Child Safety Commissioner. - 2009. From isolation to connection: A guide to understanding and working with traumatised children and young people. Melbourne, Victoria: Child Safety Commissioner.

2010. Caring classrooms: A guide to understanding truamatised children and young people - for parents and the school community. Melbourne, Victoria: Child Safety Commissioner.

Dwyer, Peter, and Johanna Wyn. 2001. Youth, education and risk: Facing the future. London: Routledge Falmer.

Edmund Rice Education Australia. 2010. Foundation Statement. http://www.youthplus.edu.au/images/docs/Youth\%20Foundation\%20Statement.pdf.

Fielding, M, and P Moss. 2011. Radical Education and the Common School. Edited by Peter Aggleton, Sally Power and Michael Reiss, Foundations and Futures of Education. Oxford: Routledge.

Foundation for Young Australians. 2013. How young people are faring 2013: The national report on the learning and earning of young Australians. Melbourne: Foundation for Young Australians.

Gay, L.R, G. E Mills, and P Airasian. 2006. Educational research: Competencies for analysis and applications. 8th ed. Upper Saddle River, NJ: Pearson Education.

Hargreaves, Andy. "Emotional Geographies of Teaching." Teachers College Record 103, no. 6 (2001): $1056-80$.

Hirst, Elizabeth, and Vadeboncoeur, Jennifer A. (2006). "Patrolling the borders of otherness: Dis/placed identity positions for teachers and students in schooled spaces." Mind, Culture and Activity, 13(3):205-227. doi: 10.1207/s15327884mca1303_4

Hodgson, David. 2007. "Towards a more telling way of understanding school leaving." Issues in Educational Research no. 17 (1):40-61.

Holdsworth. 2004. Not back to the 70s: Good practice in learning alternatives. http://www.dsf.org.au/resources-and-research/129-not-back-to-the-70s-good-practicein-learning-alternatives.

Horn, Michael, Rosanna Scutella, and Roger Wilkins. 2011. Social exclusion monitor bulletin. Research Bulletin September, http://www.bsl.org.au/Social-exclusionmonitor.

Hutchby, Ian 2005. "Active Listening": Formulations and the Elicitation of Feelings-Talk in Child Counselling." Research on Language \& Social Interaction no. 38 (3):303-329. doi: 10.1207/s15327973rlsi3803_4.

Kalantzis, Mary, and Bill Cope. 2005. Learning by design. Melbourne: Common Ground Publishing.

Lasky, Sue. 2005. "A sociocultural approach to understanding teacher identity, agency and professional vulnerability in a context of secondary school reform." Teaching and Teacher Education, 21, 899-916. doi: 10.1016/j.tate.2005.06.003

Mills, Martin, and Glenda McGregor. 2013. Reengaging young people in education: learning from alternative schools. Abingdon, Oxon, U.K: Routledge. 
Morgan, Ann. 2013. Different ways of being educator: A sociocultural exploration of educator identity and development in practice, in a system of non-traditional flexi schools. Unpublished PhD thesis. Brisbane, Australia: Griffith University.

Morgan, Ann, Raymond Brown, Deborah Heck, Donna Pendergast, and Harry Kanasa. 2013. "Professional identity pathways of educators in alternative schools: The utility of reflective practice groups for educator induction and professional learning." Reflective Practice no. 14 (2):258-270. doi: 10.1080/14623943.2012.749227.

Morgan, Ann, Donna Pendergast, Raymond Brown, and Deborah Heck. 2014. "The art of holding complexity: a contextual influence on educator identity and development in practice in a system of alternative 'flexi' schools." Reflective Practice. doi: 10.1080/14623943.2014.900020.

Nabavi, Maryam, and David Lund. 2010. "Youth and social justice: A conversation on collaborative activism." In Emancipatory practices: Adult/youth engagement for social and environmental justice, edited by W Linds, L Goulet and A Sammel, 3-14. Rotterdam: Sense Publishers.

Noddings, Nel. 1992. The challenge to care in schools: An alternative approach to education. Edited by J.F Solitis. Vol. 8, Advances in contemporary educational thought. New York: Teachers College Press. - 2005a. "Identifying and responding to needs in education." Cambridge Journal of Education no. 35 (2):147-159. doi: 10.1080/03057640500146757. . 2005b. "What does it mean to educate the whole child?" Educational Leadership no. 63 (1):9-13.

O'Connor, Kate. E. 2008. "You choose to care:" Teachers, emotions and professional identity. Teaching and Teacher Education, 24, 117-126. doi: 10.1016/j.tate.2006.11.008

Organization for Economic Cooperation and Development. 2007. Education at a glance. Paris: Organisation for Economic Co-operation and Development.

Perry, Bruce. 2009. "Examining child maltreatment through a neurodevelopmental lens: Clinical applications of the neurosequential model of therapeutics." Journal of Loss and Trauma: International Perspectives on Stress \& Coping no. 14 (4):240-255. doi: 10.1080/15325020903004350.

Perry, Bruce. 2001. "The neurodevelopmental impact of violence in childhood." In Textbook of Child and Adolescent Forensic Psychiatry, edited by D Schetky and E. P Benedek, 221-238. Washington, D.C.: American Psychiatric Press, Inc.

Rogers, C.R., and R.E. Farson. 1957. Active listening. Chicago: Industrial Relations Center, The University of Chicago.

Sachs, Judyth. 2001. "Teacher professional identity: Competing discourses, competing outcomes." Journal of Education Policy, 16(2), 149-161. doi: 10.1080/02680930116819

Slee, Roger. 2011. The irregular school: Exclusion, schooling and inclusive education. Abingdon: Routledge.

Smith, Erica. 1999. "How competency-based training has changed the role of teachers in the vocational education and training sector in Australia." Asia Pacific Journal of Teacher Education no. 27 (1).

Smith, Mark Informal education 2008. Available from www.infed.org.uk.

Smyth, John. 2003. "The making of young lives with/against the school credential." Journal of Education and Work no. 16 (2):127.

Smyth, John. 2006. "When students have 'relational' power: the school as a site for identity formation around engagement and school retention." Paper presented at the Australian Association for Research in Education, Adelaide. 
Smyth, John. 2007. "Teacher development against the policy reform grain: An argument for recapturing relationships in teaching and learning." Teacher Development: An international journal of teachers' professional development, 11(2):221-236. doi: 10.1080/13664530701414837

Smyth, John. and Robert Hattam. 2004. 'Dropping Out', Drifting Off, Being Excluded: Becoming Somebody Without School. New York: Peter Lang Publishing.

te Riele, Kitty. 2007. "Educational alternatives for marginalised youth." Australian Educational Researcher no. 34 (3):53-68.

te Riele, Kitty. 2012. Learning Choices: A Map for the Future. Report to Dusseldorp Skills Forum. Melbourne: Victoria Institute for Education, Diversity and Lifelong Learning.

te Riele, Kitty. 2014. Putting the jigsaw together: Flexible learning programs in Australia, Final Report. Melbourne: The Victoria Institute, Victoria University.

Vadeboncoeur, Jennifer.A. 2011. Youth engagement in educational contexts. In Youth+ Whole Staff Days: University of Queensland, Brisbane.

Warren, Mark. 2005. "Communities and schools: A new view of urban education reform." Harvard Educational Review no. 75 (2).

Whitby, Greg. 2013. Educating Gen Wi-Fi: How to make schools relevant for 21st-century learners. Sydney: Harper Collins.

Wyn, Johanna. 2008. The changing context of Australian youth and its implications for social inclusion. In Social Inclusion and Youth Workshop Melbourne: Brotherhood of St Laurence's. 